\title{
COMPARISON OF SEASONAL HYDROLOGIC VARIATIONS IN THE LA PLATA BASIN FROM GRACE MONTHLY SOLUTIONS WITH IN SITU TIDE GAUGE WATER LEVEL DATA
}

\author{
Annamária $\operatorname{KISS}^{1)}$ * and Lóránt FÖLDVÁRY ${ }^{2,3)}$ \\ ${ }^{1)}$ Department of Geodesy and Surveying, Budapest University of Technology and Economics, Müegyetem rkp. 3., 1111 Budapest, Hungary \\ ${ }^{2)}$ Institute of Geoinformatics, Alba Regia Technical Faculty, Óbuda University, Budai út 45., 8000 Székesfehérvár, Hungary \\ ${ }^{3)}$ Geodetic and Geophysical Institute, Research Centre of Astronomical and Earth Sciences, Hungarian Academy of Science, \\ Csatkai Endre u. 6-8, 9400 Sopron, Hungary \\ *Corresponding author's e-mail. kiss.annamaria@epito.bme.hu
}

\section{ARTICLE INFO}

Article history:

Received 3 August 2016

Accepted 27 October 2016

Available online 8 November 2016

Keywords:

Water storage variation

GRACE

Tide gauge

\begin{abstract}
Seasonal hydrologic variations have been determined in the La Plata basin from GRACE monthly solutions for a time span of less than 6 years. The results have been compared to tide gauge water level data along several rivers of the La Plata basin. Annual and semi-annual curves have been fitted both to the GRACE water storage variation series and to the tide gauge water level series, correlations between the original series and the curves have been determined, relationship of the amplitudes and phases have been investigated. The aim of the comparison is to detect time delay between the seasonal cycle of precipitation (related to GRACE) and runoff (observed by tide gauges). The time delay may deliver information on water storage, such as groundwater aquifers, soil moisture or canopy interception. As for the results, by the comparison of the annual phases, 11-13 days of time delay between GRACE data and tide gauge data has been detected.
\end{abstract}

\section{INTRODUCTION}

The Earth's constantly changing mass distribution varies its gravity field over time (Wahr and Schubert, 2007). Large-scale mass variations are generated by huge mass redistributions over large areas, such as conventions in the core and in the mantle, tectonic processes, earthquakes and volcano activity, tidal deformations of crust and oceans, circulations in the atmosphere and in the oceans, the hydrologic cycle, cryospheric processes, de-glaciation or the global sea level rise. Among them, seasonal variations are mainly generated by mass redistributions of the atmosphere, oceans and hydrologic processes.

The GRACE (Gravity Recovery And Climate Experiment) satellites have been providing global gravity field models with monthly resolution for almost 15 years, enabling the investigation of seasonal mass variations. The largest impact on seasonal gravity variations is generated by the atmosphere, which is concerned to be quite well-measured due to the dense, worldwide barometric network. For most GRACE applications, atmospheric redistribution processes are taken into account as a correction, which is found to be done in the official GRACE outputs with sufficient accuracy (Zenner et al., 2012). Over the land, the remaining seasonal mass variation is affected mainly by changes of the terrestrial water storage. After removing the mean field, which is dominated by the static density distribution inside the solid Earth, changes of the vertically integrated terrestrial water storage can be determined (Ilk et al., 2005). As inside a basin GRACE data is characterized by the seasonal hydrologic mass variations, relationship with the seasonal variations of the runoff along the rivers of the catchment area can be expected. In this study water storage variations have been determined from GRACE models in the South American La Plata basin between 2002 and 2008, and compared with tide gauge water levels along the main rivers of the basin, with particular emphasis on the seasonal trends.

Earlier studies for the La Plata basin have been delivered by Pereira and Pacino (2012) and Pereira et al. (2012). Both studies deliver a regional analysis of hydrological processes based on GRACE monthly solutions. The present study does not focus on the whole basin as a region, instead point-wise comparison of the satellite derived data with tide gauge water level observations is performed. The difference of the two observations is expected to provide information on the water storage variations, since tide gauge observes the real time runoffs, while GRACE reflects all mass variations over the region, including the subsurface water variations as well. Some incomplete investigations have already been 


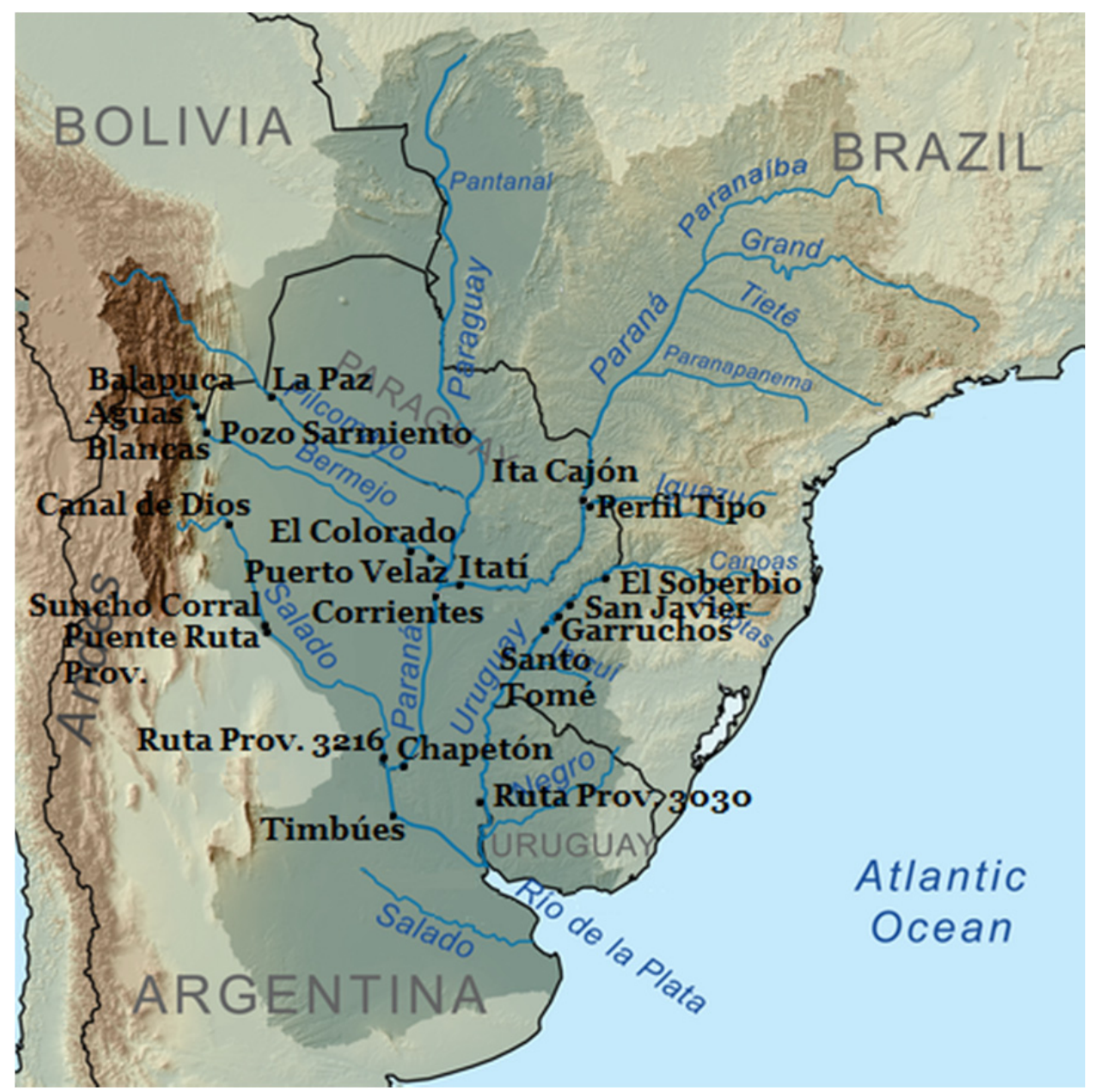

Fig. 1 The main rivers of the La Plata basin and the locations of the available tide gauge data.

performed by Kiss and Földváry (2015), which has been refined in the processing methodology, and the conclusions have been elaborated for the present study.

\section{DATA}

The hydrological data from January 2002 till January 2008 is obtained in daily resolution. Gauged water level time series are available from the Argentinean area of the basin, consisting 21 hydrologic stations of 7 rivers.

Table 1 contains information of the stations, arranged by river with increasing distance from the estuary. The suitability of the tide gauge data is highly dependent of the location of the hydrologic station. The river regulations have large effects on the water level, leading to distorted seasonal signals. Many of these rivers are affected by the Guarani aquifer, located beneath most of the area of the basin (approximately $80 \%$ ). This large groundwater system causes the lack of the seasonal water level variations along the Paraná, Uruguay, Salado, Gualeguaychú and Iguazú rivers. Furthermore, there are hydroelectric dams on the Paraná (Itaipú and Yaciretá), Uruguay (Salto Grande and Itá) and Salado (Cabra Corral) rivers. In addition, waterfalls such as the Iguazú (Paraná and Iguazú rivers) and Moconá (Uruguay River) and other reservoirs and irrigation canals make 5 out of 7 rivers infeasible for studying seasonal mass variations. The 6 hydrologic stations of the Bermejo and Pilcomayo rivers are completely free from these effects, thus water level series along these rivers are likely to reflect the seasonal characteristics. Hence, our study is limited to the results of these 6 hydrological stations.

As for the gravity field solutions, models of different processing centres may notably differ at certain regions. In fact, Klees et al. (2008) has found that phases of the models delivered by the Jet Propulsion Laboratory (JPL) and the Delft Institute of Earth Observation and Space Systems (DEOS) differ statistically significant from the phases of the Centre National d'Etudes Spatiales (CNES), the GeoForschungsZentrum Potsdam (GFZ) and the Center for Space Research, University of Texas (CSR) models over the period from February 2003 to 
Table 1 Parameters of the hydrological stations.

\begin{tabular}{|c|c|c|c|c|c|c|}
\hline RIVER/Station & ID & Distance $(\mathrm{km})$ & Latitude & Longitude & Sampling & Interval \\
\hline \multicolumn{7}{|l|}{ BERMEJO } \\
\hline Puerto Velaz & 2610 & 35 & $-26^{\circ} 39^{\prime} \mathrm{S}$ & $-58^{\circ} 37^{\prime} \mathrm{W}$ & daily & 2002.01.-2008.12 \\
\hline El Colorado & 2602 & 124 & $-26^{\circ} 20^{\prime} 04^{\prime \prime} \mathrm{S}$ & $-59^{\circ} 21^{\prime} 45^{\prime \prime} \mathrm{W}$ & daily & 2002.01.-2008.12 \\
\hline Pozo Sarmiento & 693 & 783 & $-23^{\circ} 08^{\prime} 26^{\prime \prime} \mathrm{S}$ & $-64^{\circ} 11^{\prime} 49^{\prime \prime} \mathrm{W}$ & daily & 2002.01.-2008.12 \\
\hline Aguas Blancas & 604 & 826 & $-22^{\circ} 43^{\prime} 30^{\prime \prime} \mathrm{S}$ & $-64^{\circ} 21^{\prime} 53^{\prime \prime} \mathrm{W}$ & daily & 2002.01.-2008.12 \\
\hline Balapuca & 605 & 858 & $-22^{\circ} 29^{\prime} 33^{\prime \prime} \mathrm{S}$ & $-64^{\circ} 27^{\prime} 49^{\prime \prime} \mathrm{W}$ & daily & 2002.01.-2008.12 \\
\hline \multicolumn{7}{|l|}{ GUALEGUAYCHÚ } \\
\hline Ruta Prov. & 3030 & 76 & $-32^{\circ} 26^{\prime} 42^{\prime \prime} \mathrm{S}$ & $-58^{\circ} 33^{\prime} 18^{\prime \prime} \mathrm{W}$ & daily & 2002.01.-2008.12 \\
\hline \multicolumn{7}{|l|}{ IGUAZÚ } \\
\hline Perfil Tipo & 3440 & 28 & $-25^{\circ} 40^{\prime} \mathrm{S}$ & $-54^{\circ} 25^{\prime} \mathrm{W}$ & daily & 2002.01.-2008.12 \\
\hline \multicolumn{7}{|l|}{ PARANÁ } \\
\hline Timbúes & 3316 & 279 & $-32^{\circ} 43^{\prime} 11^{\prime \prime} \mathrm{S}$ & $-60^{\circ} 43^{\prime} 34^{\prime \prime} \mathrm{W}$ & hourly & 2003.01.-2007.12 \\
\hline Chapetón & 3005 & 430 & $-31^{\circ} 38^{\prime} 48^{\prime \prime} \mathrm{S}$ & $-60^{\circ} 16^{\prime} 44^{\prime \prime} \mathrm{W}$ & daily & 2002.01.-2008.12 \\
\hline Chapetón & 3005 & 430 & $-31^{\circ} 38^{\prime} 48^{\prime \prime} \mathrm{S}$ & $-60^{\circ} 16^{\prime} 44^{\prime \prime} \mathrm{W}$ & monthly & 2001.12.-2007.09 \\
\hline Corrientes & 3805 & 940 & $-27^{\circ} 27^{\prime} 55^{\prime \prime} \mathrm{S}$ & $-58^{\circ} 50^{\prime} 57^{\prime \prime} \mathrm{W}$ & daily & 2002.01.-2008.12 \\
\hline Corrientes & 3805 & 940 & $-27^{\circ} 27^{\prime} 55^{\prime \prime} \mathrm{S}$ & $-58^{\circ} 50^{\prime} 57^{\prime \prime} \mathrm{W}$ & monthly & 2001.12.-2007.08 \\
\hline Itatí & 3862 & 1007 & $-27^{\circ} 15^{\prime} 59^{\prime \prime} \mathrm{S}$ & $-58^{\circ} 14^{\prime} 38^{\prime \prime} \mathrm{W}$ & monthly & 2001.12.-2007.08 \\
\hline Ita Cajón & 3452 & 1542 & $-25^{\circ} 36^{\prime} \mathrm{S}$ & $-54^{\circ} 35^{\prime} \mathrm{W}$ & monthly & 2001.12.-2007.08 \\
\hline \multicolumn{7}{|l|}{ PILCOMAYO } \\
\hline $\mathrm{LaPaz}$ & 631 & 626 & $-22^{\circ} 22^{\prime} 38^{\prime \prime} \mathrm{S}$ & $-62^{\circ} 31^{\prime} 23^{\prime \prime} \mathrm{W}$ & daily & 2002.01.-2008.12 \\
\hline \multicolumn{7}{|l|}{ SALADO } \\
\hline Ruta Prov. & 3216 & 34 & $-31^{\circ} 29^{\prime} \mathrm{S}$ & $-60^{\circ} 47^{\prime} \mathrm{W}$ & daily & 2002.01.-2008.12 \\
\hline Puente Ruta Prov. & 811 & 563 & $-28^{\circ} 30^{\prime} 13^{\prime \prime} \mathrm{S}$ & $-62^{\circ} 52^{\prime} 53^{\prime \prime} \mathrm{W}$ & daily & 2004.06.-2008.12 \\
\hline Suncho Corral & 804 & 655 & $-27^{\circ} 56^{\prime} 25^{\prime \prime} \mathrm{S}$ & $-63^{\circ} 26^{\prime} 23^{\prime \prime} \mathrm{W}$ & daily & 2004.06.-2008.12 \\
\hline Canal de Dios & 810 & 951 & $-25^{\circ} 37^{\prime} 36^{\prime \prime} \mathrm{S}$ & $-63^{\circ} 57^{\prime} 00^{\prime \prime} \mathrm{W}$ & daily & 2002.01.-2008.12 \\
\hline \multicolumn{7}{|l|}{ URUGUAY } \\
\hline Santo Tomé & 3860 & 720 & $-28^{\circ} 32^{\prime} \mathrm{S}$ & $-56^{\circ} 01^{\prime} \mathrm{W}$ & daily & 2002.01.-2008.12 \\
\hline Garruchos & 3857 & 791 & $-28^{\circ} 10^{\prime} 37^{\prime \prime} \mathrm{S}$ & $-55^{\circ} 38^{\prime} 31^{\prime \prime} \mathrm{W}$ & daily & 2002.01.-2008.12 \\
\hline San Javier & 3449 & 856 & $-27^{\circ} 52^{\prime} \mathrm{S}$ & $-55^{\circ} 08^{\prime} \mathrm{W}$ & daily & 2002.01.-2008.12 \\
\hline El Soberbio & 3442 & 978 & $-27^{\circ} 17^{\prime} 55^{\prime \prime} \mathrm{S}$ & $-54^{\circ} 11^{\prime} 37^{\prime \prime} \mathrm{W}$ & daily & 2002.01.-2008.12 \\
\hline
\end{tabular}

February 2006. Similarly, Pereira and Pacino (2012) and Pereira et al. (2012) found slight difference of CNES, GFZ and CSR models, but all models differ notably from JPL model. Note that Pereira and Pacino (2012) have found the difference to be much less than it is stated by Klees et al. (2008). According to our tests (considering CSR, GFZ and JPL solutions only), the difference of these solutions is also not that relevant, the estimate of Pereira and Pacino (2012) and Pereira et al. (2012) is more similar to ours.

Generally, in order to avoid the use of an extreme, an 'average' model was aimed to be chosen for the present analysis. During our tests with the method and parameterization (see Methodology section), the CSR model have been found being not striking to any extremes. Based on the tests, the GRACE RL05 Level-2 products of CSR have been used (RL05). The first GRACE models dated to April 2002 , thus the overlap period with the time span of 6 years of the tide gauge data is from April 2002 to January 2008. During this period 66 models of
GRACE monthly solutions are available. For practical reasons 148 models from the period of April 2002 and December 2015 have been used instead (see Methodology section).

\section{METHODOLOGY}

Based on the RL05 spherical harmonic coefficients derived from the GRACE measurements, surface mass density changes can be determined by the methodology of Swenson and Wahr (2002). Surface mass density variations with monthly resolution are dominated by the mass variations of ocean and hydrology over the test area. The area of the basin has been outlined by the method of Longuevergne et al. (2010) to reduce mass variation effects of the neighbouring regions and of the ocean, thus the remaining signal may be assumed to be generated by hydrological processes within the $\mathrm{La}$ Plata basin. Surface mass variations have been calculated to the locations of the hydrologic stations, and the observed periodic signal has been compared to 
tide gauge measurements. The maximal degree of the spherical harmonics has been truncated at $l=60$. In order to eliminate the striping features of the GRACE monthly solutions, a Gaussian smoothing with radius $r=300 \mathrm{~km}$ and a de-striping filter (Swenson and Wahr, 2006) have been applied. To quantify the results of the comparison, annual and semi-annual curves have been fitted to the tide gauge level time series:

$$
\begin{aligned}
f(t) & =a+b \cdot t+c \cdot \sin \left(\omega_{\text {annual }} \cdot t+\varphi_{c}\right)+ \\
& +d \cdot \sin \left(\omega_{\text {semi-annual }} \cdot t+\varphi_{d}\right)
\end{aligned}
$$

and the GRACE-borne mass variation series:

$$
\begin{aligned}
g(t) & =a+b \cdot t+c \cdot \frac{1}{\sin c\left(\frac{1}{12}\right)} \cdot \sin \left(\omega_{\text {anпиа }} \cdot t+\varphi_{c}\right)+ \\
& +d \cdot \frac{1}{\sin c\left(\frac{1}{6}\right)} \cdot \sin \left(\omega_{\text {semi-annual }} \cdot t+\varphi_{d}\right)
\end{aligned}
$$

where $a$ is bias, $b$ is trend, $c$ and $d$ are annual and semi-annual amplitudes, $\varphi_{c}$ and $\varphi_{d}$ are annual and semi-annual phases, $\omega_{\text {annual }}=1$ and $\omega_{\text {semi-annual }}=1 / 2$ correspond to annual and semi-annual variations and $t$ is the actual date. The $1 /$ sinc multipliers in equation (2) are applied to restore the temporal averaging of the GRACE measurements (Földváry, 2015).

A period of slightly less than 6 years is very short for reliable estimation of annual and semi-annual mass variations, since any non-seasonal impact, such as effects of the El Niño-Southern Oscillation during this period may influence notably the estimation. Thus, the period has been extended to much longer data, up to December 2015. The estimated annual and semi-annual amplitudes and phases were used for the comparison. However, as the analysis refers to the period from April 2002 to January 2008, a signal has been calculated only for this time span, and used for the statistics.

The adjustment of the GRACE time series was performed by least squares method:
$x=\left(A^{T} \cdot A\right)^{-1} \cdot\left(A^{T} \cdot l\right)$

where $A$ is the design matrix, $l$ is the observation vector, and $x$ is the vector of unknown parameters containing $a, b, c, d, \varphi_{c}$ and $\varphi_{d}$.

As the residuals of the tide gauge water level series were found not to follow the normal distribution, those have been adjusted by a robust method:

$x=\left(A^{T} \cdot P \cdot A\right)^{-1} \cdot\left(A^{T} \cdot P \cdot l\right)$

where the elements of $P$ are set by an exponential weight function:

$p=\exp \left(-k_{1} \cdot\left|\frac{v}{\sigma_{v}}\right|^{k_{2}}\right)$

where $v$ is the residual, $\sigma_{v}$ is the standard deviation of the residuals, and the values of $k_{1}, k_{2}$ are determined empirically (Huber, 1964). In our case these were set to $k_{1}=0.05$ and $k_{2}=4.4$, as suggested by Soha (1986).

Equations (3) and (4) are not linear for the unknowns, thus an iterative solution has been used. Also, the correlation between the seasonal curves and the corresponding time series (GRACE surface mass anomalies or tide gauge water levels) has been determined.

\section{RESULTS AND DISCUSSION}

The tide gauge time series and the fitted seasonal curves are shown in Figure 2, and summarized in Table 2. The adjustment of the tide gauge time series yields $0.7-0.9$ correlation values, as it is anticipated by the visually striking seasonal characteristics of the signal. The amplitude of the annual variation generally increases by approaching the Bermejo river estuary, which is in accordance with the increasing amount of water received from the inflowing rivers.

\begin{tabular}{|c|c|c|c|c|c|c|c|}
\hline Station & ID & $\begin{array}{c}\text { Distance } \\
(\mathrm{km})\end{array}$ & $\begin{array}{c}\text { Annual } \\
\text { amplitude } \\
\text { (m) }\end{array}$ & $\begin{array}{c}\text { Annual } \\
\text { phase } \\
\text { (days) }\end{array}$ & $\begin{array}{c}\text { Semi-annual } \\
\text { amplitude } \\
(\mathrm{m})\end{array}$ & $\begin{array}{c}\text { Semi-annual } \\
\text { phase } \\
\text { (days) }\end{array}$ & Correlation \\
\hline \multicolumn{8}{|c|}{ BERMEJO RIVER } \\
\hline Puerto Velaz & 2610 & 35 & 2.522 & 7.1 & 0.775 & -9.7 & 0.9154 \\
\hline El Colorado & 2602 & 124 & 2.334 & 8.4 & 0.816 & -9.9 & 0.9056 \\
\hline Pozo Sarmiento & 693 & 783 & 0.956 & 16.1 & 0.190 & +0.8 & 0.7478 \\
\hline Aguas Blancas & 604 & 826 & 0.527 & 16.6 & 0.112 & -2.0 & 0.7801 \\
\hline Balapuca & 605 & 858 & 0.916 & 17.5 & 0.206 & -3.1 & 0.8030 \\
\hline \multicolumn{8}{|c|}{ PILCOMAYO RIVER } \\
\hline $\mathrm{La} \mathrm{Paz}$ & 631 & 626 & 0.678 & 22.5 & 0.190 & 5.6 & 0.6786 \\
\hline
\end{tabular}
The annual phases are larger at the source, i.e. the annual period appears earlier at the estuary.

Table 2 Results of the tide gauge time series fitting. 

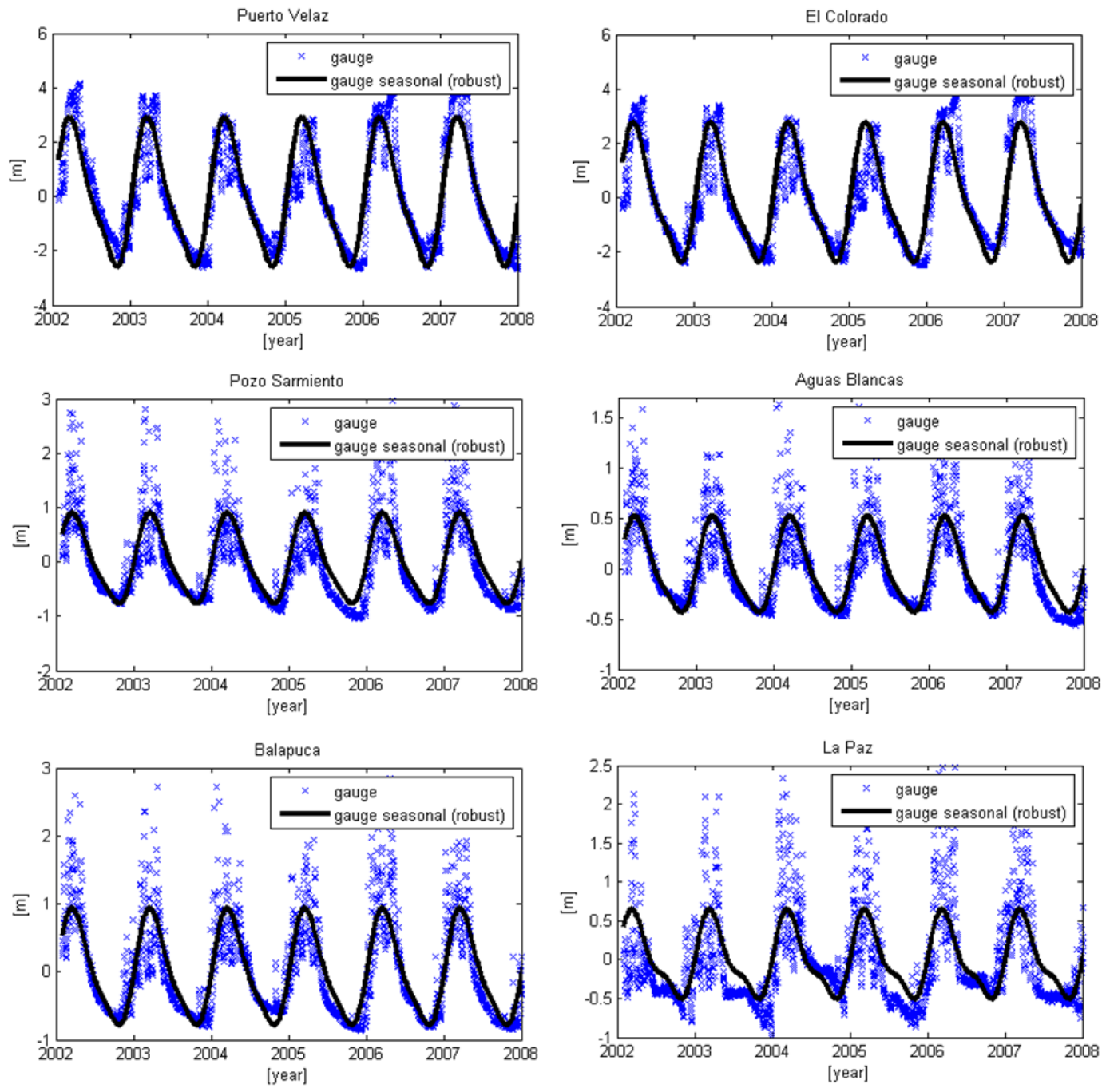

Fig. 2 Fitting of seasonal variation curves on tide gauge data of Puerto Velaz, El Colorado, Pozo Sarmiento, Aguas Blancas, Balapuca and La Paz stations.

The mass variations determined from GRACE gravity models and the fitted seasonal variations are displayed in Figure 3, and the results are collected in Table 3. The GRACE correlations show successful fitting at the river sources, where also relevant seasonal variations were observed. However, low correlation and smaller amplitudes at the estuary were found. In contrary to the tide gauge results, the GRACE annual amplitudes are higher at the sources, which can be explained by the different content of the observed signals. GRACE measures the entire water mass variation, not only the runoff, and as the hydrology related mass variation gets more complex by approaching to the estuary, including a huge contribution of the underground waters, the seasonality becomes more distorted, aliased by the variations of the wetland water storage, contributed by groundwater aquifers, soil moisture and canopy interception. Nevertheless, annual phases show consequently lower values than that of the tide gauge results.
Comparing the tide gauge and GRACE results, c.f. Figure 4, it is conspicuous that the tide gauge annual amplitudes are the multiples of the GRACE amplitudes. This is a consequence of the essential difference of water mass variation and gauged water level. In Figure 4, scaling factors have been applied to make the curves comparable, c.f. 4th column of Table 4. Generally, the annual scale was found to increase by approaching to the estuary. Earlier studies have also been applied a scale factor when compared GRACE-borne mass variation with gauged water level measurements. Andersen et al. (2008) used a value around 10 for the scaling at the Chandpur River. Vaz de Almeida et al. (2012) have been studied the Amazon basin and calculated with scale factors between 10 and 20. The observed 18-42 annual scale factors in this study are slightly higher than these results, with the exception of station Puerto Valez and El Colorado, close to the estuary of the Bermejo River, in which cases the large $(>100)$ scale factors 

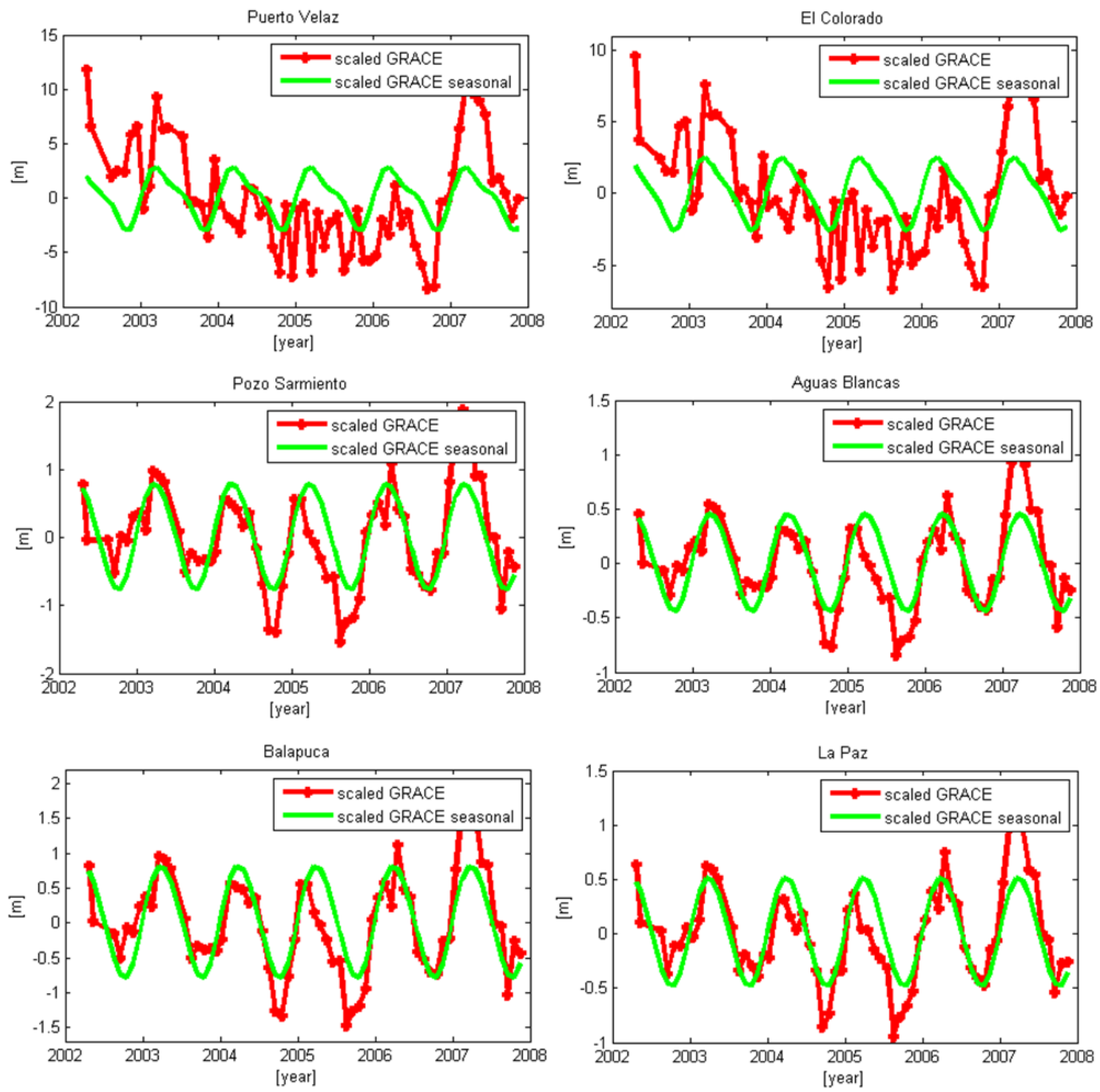

Fig. 3 GRACE-borne monthly surface mass anomaly data and the best fitting seasonal variation curves at the Puerto Velaz, El Colorado, Pozo Sarmiento, Aguas Blancas, Balapuca and La Paz stations.

Table 3 Results of the GRACE time series fitting, determined for the period 2002-2015, correlation for 20022008.

\begin{tabular}{|c|c|c|c|c|c|c|c|}
\hline Station & ID & $\begin{array}{c}\text { Distance } \\
(\mathrm{km})\end{array}$ & $\begin{array}{c}\text { Annual } \\
\text { amplitude } \\
\text { (m) }\end{array}$ & $\begin{array}{l}\text { Annual } \\
\text { phase } \\
\text { (days) }\end{array}$ & $\begin{array}{c}\text { Semi-annual } \\
\text { amplitude }(\mathrm{m})\end{array}$ & $\begin{array}{c}\text { Semi-annual } \\
\text { phase } \\
\text { (days) }\end{array}$ & Correlation \\
\hline \multicolumn{8}{|c|}{ BERMEJO RIVER } \\
\hline Puerto Velaz & 2610 & 35 & 0.021 & -168.6 & 0.007 & -3.4 & 0.2174 \\
\hline El Colorado & 2602 & 124 & 0.017 & -24.8 & 0.005 & 5.2 & 0.1068 \\
\hline Pozo Sarmiento & 693 & 783 & 0.018 & 4.8 & 0.006 & -34.0 & 0.6553 \\
\hline Aguas Blancas & 604 & 826 & 0.019 & 4.5 & 0.006 & -32.2 & 0.6886 \\
\hline Balapuca & 605 & 858 & 0.019 & 4.6 & 0.006 & -31.3 & 0.7022 \\
\hline \multicolumn{8}{|c|}{ PILCOMAYO RIVER } \\
\hline La Paz & 631 & 626 & 0.025 & 11.3 & 0.006 & -16.6 & 0.7411 \\
\hline
\end{tabular}

and the low correlation of the seasonal fitting are interpreted by the aliased GRACE mass variation estimate.

Only a few days of annual phase difference between the GRACE and tide gauge time series were detected, which shows how much time it takes for precipitation to dominate in the runoff. The detected values are in accordance with hydrologic model results.

Semi-annual variations were found to be approximately an order of magnitude smaller than annual variations. Results for the semi-annual 

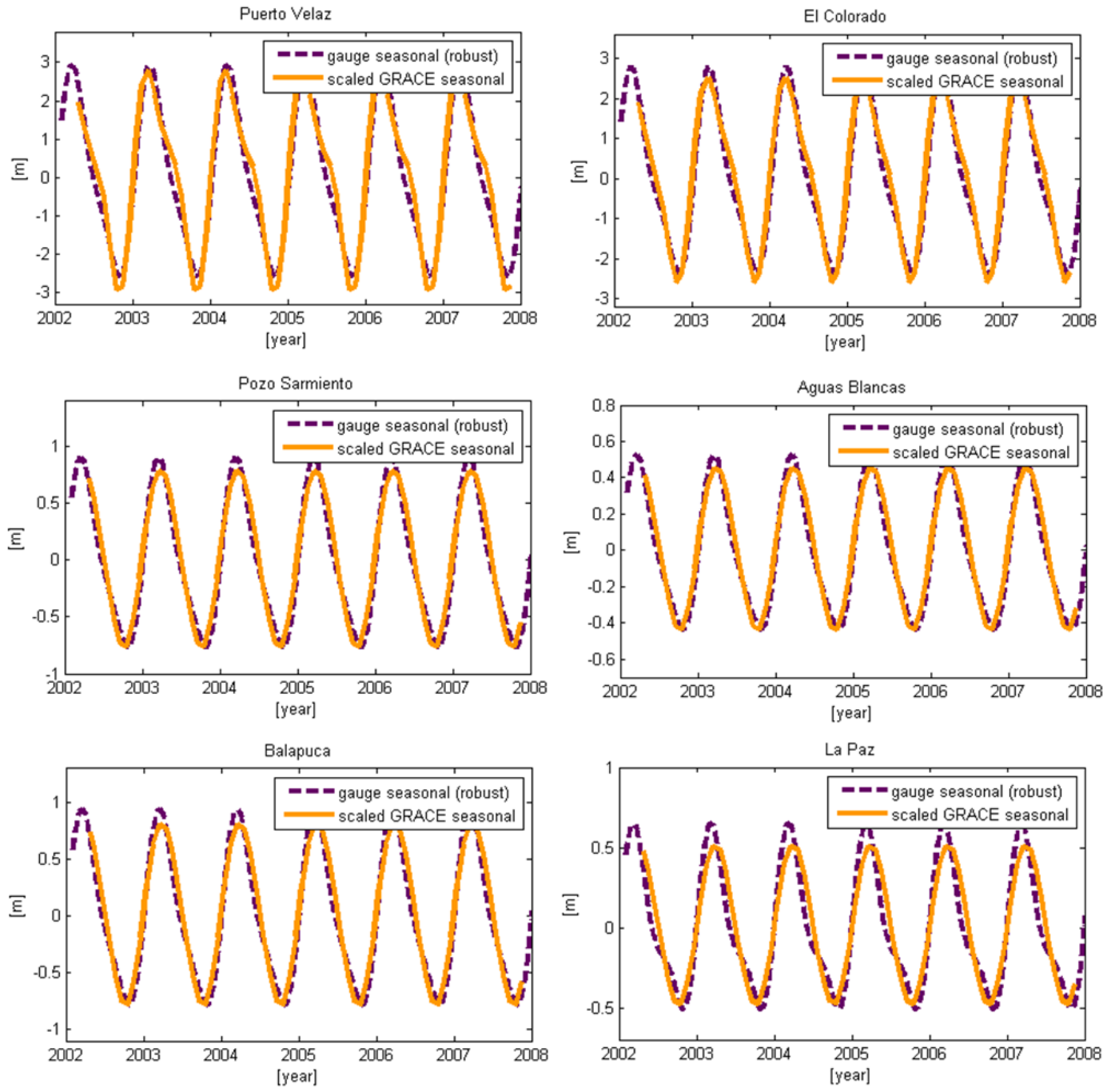

Fig. 4 Comparison of seasonal GRACE-borne and tide gauge mass variations at the Puerto Velaz, El Colorado, Pozo Sarmiento, Aguas Blancas, Balapuca and La Paz stations.

Table 4 Comparison of annual GRACE-borne mass variations and gauged annual water level signals.

\begin{tabular}{lcccccccc}
\hline Station & ID & $\begin{array}{c}\text { Distance } \\
(\mathrm{km})\end{array}$ & $\begin{array}{c}\text { Annual } \\
\text { scale }\end{array}$ & $\begin{array}{c}\text { Annual } \\
\text { phase } \\
\text { difference } \\
\text { (days) }\end{array}$ & $\begin{array}{c}\text { Semi- } \\
\text { annual } \\
\text { scale }\end{array}$ & $\begin{array}{c}\text { Semi-annual } \\
\text { phase } \\
\text { difference } \\
\text { (days) }\end{array}$ & $\begin{array}{c}\text { Tide } \\
\text { gauge } \\
\text { correlation }\end{array}$ & $\begin{array}{c}\text { GRACE } \\
\text { correlation }\end{array}$ \\
\hline $\begin{array}{l}\text { BERMEJO RIVER } \\
\text { Puerto Velaz }\end{array}$ & 2610 & 35 & 123.9 & 175.7 & 105.7 & -6.3 & 0.9154 & 0.2174 \\
El Colorado & 2602 & 124 & 142.8 & 33.2 & 159.6 & -15.1 & 0.9056 & 0.1068 \\
Pozo Sarmiento & 693 & 783 & 41.66 & 11.3 & 30.96 & 34.8 & 0.7478 & 0.6553 \\
$\quad \begin{array}{l}\text { Aguas Blancas } \\
\text { Balapuca }\end{array}$ & 604 & 826 & 22.82 & 12.1 & 18.45 & 30.2 & 0.7801 & 0.6886 \\
$\begin{array}{l}\text { PILCOMAYO RIVER } \\
\text { La Paz }\end{array}$ & 631 & 626 & 39.47 & 12.9 & 33.83 & 28.2 & 0.8030 & 0.7022 \\
\hline
\end{tabular}

variations yielded to inconsistent results both in scale and phase shift, as the notably larger mass content of the annual frequency overwhelms the runoff characteristics.

\section{CONCLUSIONS}

The tide gauge time series data along rivers of the La Plata Basin have been compared with GRACE derived mass variations for a period of 6 years, between 2002 and 2008. The comparison should be considered critically as the two kinds of measurements are weakly connected to each other, since GRACE detects vertically integrated mass variation regardless the height / depth of the source, while tide gauges observe real time surface runoff only. On the other hand, it is obvious that the 
phenomena are strictly connected to each other: precipitation must appear in the runoff sooner or later. The time delay between precipitation and runoff is caused by different forms of water storage, such as groundwater aquifers, soil moisture or canopy interception. The time delay due to water storage is estimated in this study as the difference in the seasonal cycle of the precipitation and water storage (GRACE) and runoff (tide gauge).

The investigation has lead to the following results.

1) It was found that rivers under heavy water control, i.e. dams, and the Guarani aquifer alias so much the periodicity of the nearby water mass variations that no relevant annual or semi-annual period can be seen neither on GRACE nor on tide gauge water level data. Among the 7 rivers only 2 could be used for further analysis.

2) Close to the estuary of a river the periods of the different influents and subsurface sources are so much mixed that no relevant annual and semi-annual period could be determined. Along the investigated 6 hydrologic stations 2 (at estuary distance of 35 and $124 \mathrm{~km}$ ) have been excluded, the remaining 4 stations has been located from the estuary at $626,783,826$ and $858 \mathrm{~km}$.

3) Based on these 4 stations, time delay between precipitation and runoff has been found to be 1113 days on annual period.

4) Semi-annual variations are an order of magnitude smaller than annual variations, and are overwhelmed by the annual variations. Semi-annual variations showed a time delay of 22-35 days, but these are considered to be inconsistent due to its inconsistency both in scale and phase shift.

\section{ACKNOWLEDGEMENT}

The authors are grateful for Prof. Maria Cristina Pacino and Dr. Ayelen Pereira for providing the tide gauge water level data in the La Plata basin.

\section{REFERENCES}

Andersen, O., Berry, P., Freeman, J., Lemoine, F.G., Luthcke, S., Jakobsen, K. and Butts, M.: 2008, Satellite altimetry and GRACE gravimetry for studies of annual water storage variations in Bangladesh. Terr. Atmos. Ocean Sci., 19, 47-52. DOI:10.3319/TAO.2008.19.1-2.47(SA)

Földváry, L.: 2015, Desmoothing of averaged periodical signals for geodetic applications. Geophysical Journal International, 201 (3), 1235-1250.

DOI $10.1093 /$ gji $/$ ggv092

Huber, P.J.: 1964, Robust estimation of a location parameter. Ann. Mathem. Statist., Princetown 35.

Ilk, K.H., Flury, J., Rummel, R., Schwintzer, P. Bosch, W., Haas, C., Schröter, J., Stammer, D., Zahel, W., Miller, H., Dietrich, R., Huybrechts, P., Schmeling, H., Wolf, D., Götze, H.J., Riegger, J., Bardossy, A., Günter, A. and Gruber, Th.: 2005, Mass transport and mass distribution in the Earth system. Contributions of the new generation of satellite gravity and altimetry missions to the Geosciences. Proposal for a German priority research program 2 nd ed., GOCE-Projektbüro TU München, GeoForschungsZentrum Potsdam, München, Potsdam.

Kiss, A. and Földváry, L.: 2015, Annual hydrologic variations from GRACE gravity models. Geomatikai Közlemények, XVIII/2, 43-52, (in Hungarian).

Klees, R., Liu, X., Wittwer, T., Gunter B.C., Revtova, E.A., Tenzer, R., Ditmar, P., Winsemius, H.C. and Savenije, H.H.G.: 2008, A comparison of global and regional GRACE models for land hydrology. Surv Geophys, 29, 335-359. DOI: 10.1007/s10712-008-9049-8

Longuevergne, L., Scanlon, B.R. and Wilson, C.R.: 2010, GRACE hydrological estimates for small basins: Evaluating processing approaches on the High Plains Aquifer, USA. Water Resour. Res., 46, W11517. DOI: 10.1029/2009WR008564

Pereira, A. and Pacino, M.C.: 2012, Annual and seasonal water storage changes detected from GRACE data in the La Plata Basin. Physics of the Earth and Planetary Interiors, 212-213, 88-99. DOI: $10.1016 /$ j.pepi.2012.09.005

Pereira, A., Miranda, S., Pacino, M.C. and Forsberg, R.: 2012, Water storage changes from GRACE data in the La Plata basin. In Proceedings of IAG Symposium in Buenos Aires, eds. Kenyon, S.C., Pacino, M.C. and Marti, U.J., IAG Symposia Series, 131, 147-152, Springer Heidelberg Dordrecht London New York.

Soha, G.: 1986, A method of robust adjustment with corrections dependent weighting. Geodézia és Kartográfia, 4, 267-271, (in Hungarian).

Swenson, S. and Wahr, J.: 2002, Methods for inferring regional surface-mass anomalies from GRACE measurements of time-variable gravity. J. Geophys. Res., 107(B9), 2193. DOI: 10.1029/2001JB000576

Swenson, S. and Wahr, J.: 2006, Post-processing removal of correlated errors in GRACE data. Geophysical Research Letters, 33, L08402. DOI: $10.1029 / 2005$ GL025285

Vaz de Almeida Filho, F.G., Calmant, S., Seyler, F., Ramillien, G., Blitzkow, D., Matos, A.C.C. and Silva, S.J.: 2012, Time-variations of equivalent water heights from Grace Mission and in-situ river stages in the Amazon basin. Acta Amazonica (Impresso), 42, 125134.

Wahr, J. and Schubert, G. (Ed.): 2007, Time variable gravity from satellites. Treatise on Geophysics, 213-218, Oxford, Elsevier Ltd.

Zenner, L., Gruber, Th., Beutler, G., Jäggi, A., Flechtner, F., Schmidt, T., Wickert, J., Fagiolini, E., Schwarz, G. and Trautmann, T.: 2012, Using atmospheric uncertainties for GRACE de-aliasing: first results, In: Proceedings of IAG Symposium in Buenos Aires, eds. Kenyon, S.C., Pacino, M.C. and Marti, U.J. IAG Symposia Series, 131, 147-152, Springer Heidelberg Dordrecht London New York. 